\section{An unusual cause of intestinal obstruction in an adolescent: a case report and management review}

\author{
Victor Hip-Wo Yeung, Nicholas Sik-Yin \\ Chao, Michael Wai-Yip Leung, \\ Wing-Kin Kwok \\ Division of Pediatric Surgery, \\ Department of Surgery, Queen Elizabeth \\ Hospital, Hong Kong
}

\section{Abstract}

A 15-year-old boy presented with intestinal obstruction two weeks following a blunt abdominal trauma. He had progressive bilious vomiting without abdominal distension or peritonitis. The contrast computed tomography (CT) scan of the abdomen provided the definitive diagnosis: there was an obstructing duodenal hematoma, which might have been slowly progressing or have arisen from secondary hemorrhage after the initial injury. The boy remained stable over a ten-day period of conservative treatment, and his obstructive symptoms and signs were resolved completely. A follow-up CT scan of the abdomen (16 days after admission) showed an almost complete resolution of the hematoma. Delayed duodenal hematoma causing intestinal obstruction has been reported rarely in previous literature. Occasionally a significant secondary hemorrhage resulting in intestinal obstruction can become life threatening. Clinical follow-up is paramount after initial recovery. Although conservative treatment suffices in most cases, the surgeon should be wary of the need for definitive surgical intervention if there is evidence of ongoing acute hemorrhage or of the obstructing hematoma failing to resolve. Laparoscopic drainage of the hematoma provides optimistic results for patients failing conservative management.

\section{Introduction}

Duodenal hematoma secondary to blunt abdominal injury in children commonly causes intestinal obstruction within a few days after the incident. In addition, it is difficult to diagnose duodenal hematoma clinically in view of its nonspecific presentation, including symptoms of nausea, vomiting, abdominal pain, and no bowel output, as well as signs of right upper abdomen or epigastric tenderness. We report a case of an adolescent with a delayed presentation of duodenal hematoma (two weeks after the injury), and review the management of such a condition.

\section{Case Report}

A 15-year-old adolescent presented at our hospital with a history of physical assault two weeks prior to admission. He volunteered that he was hit on the face, the four limbs, as well as the abdomen. He also suffered from minor scald injuries mainly over his back after being splashed with hot water. In addition, he complained of vague abdominal discomfort principally in the right upper quadrant as well as epigastric areas, associated with nausea and bilious vomiting, and he had had no bowel movements for two days.

On examination he was afebrile and his vital signs were stable. Air entry over both his lungs was equal. His heart sounds were dual, and there was no audible murmur. His abdomen was mildly distended and tender in the right upper quadrant and epigastric regions. No mass was felt in the abdomen, and his bowel sounds were sluggish. Neurological examination showed no abnormality. Routine laboratory investigations showed a mild drop in hemoglobin, but the white blood cells and platelets were normal. The renal and liver function tests including amylase were within normal limits. The clotting profile was normal as well. An abdominal X-ray (Figure 1) showed a dilated stomach with an air-fluid level over the stomach and a scanty bowel shadow. A brain CT scan was performed to rule out brain pathology, and the result was normal. An abdominal CT scan with contrast was performed (Figure 2); there was an elongated fluid collection over the second part of the duodenum, suggestive of a concealed hematoma. Irregularity was noted in the lateral wall of the first and second part of the duodenum, but no

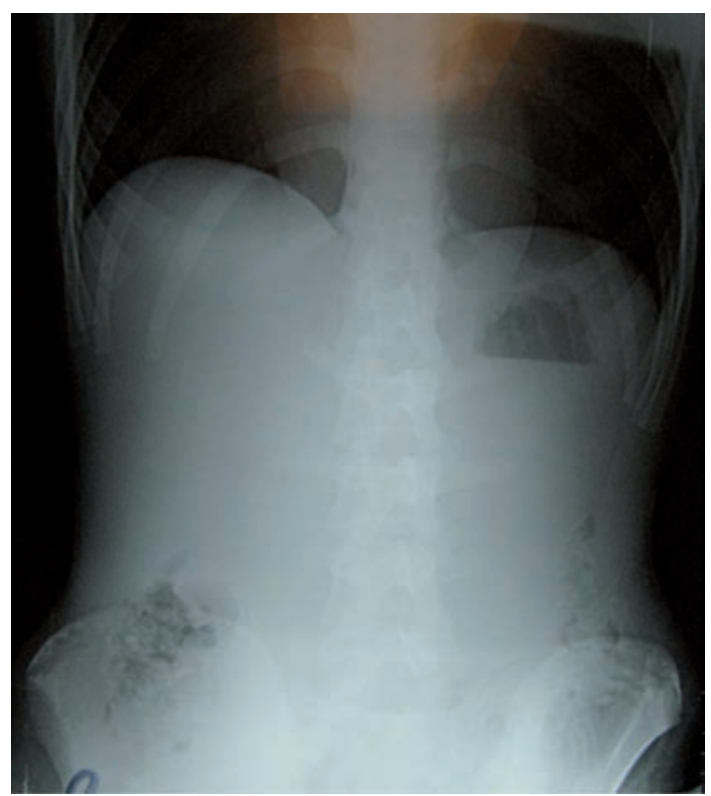

Correspondence: Victor Hip Wo Yeung, 4/B Robinson Garden Apartments, 3 Robinson Road, Mid-levels, Hong Kong.

E-mail: yeesung@gmail.com

Key words: adolescent, blunt abdominal trauma duodenal hematoma, intestinal obstruction.

Contributions: VHWY study design, review of hospital notes, editing of figures, write-up of the manuscript; NSYC, MWYL, WKK review and editing of the manuscript.

Conflict of interest: the authors report no conflicts of interest.

Received for publication: 19 July 2009

Accepted for publication: 26 October 2009

This work is licensed under a Creative Commons Attribution 3.0 License (by-nc 3.0).

(C) Copyright V.H.W. Yeung et al., 2009

Pediatric Reports 2009; 1:e8

doi:10.4081/pr.2009.e8

leakage of contrast was noted. This supported the diagnosis of a duodenal hematoma.

The patient was put on nil-by-mouth, and was given total parenteral nutrition (TPN). A nasogastric tube was inserted for drainage and decompression. Originally the bile-stained output was high: $1200 \mathrm{~mL} /$ day, but eventually dropped down to about $150 \mathrm{~mL} /$ day on day 10 after admission. The Ryle's tube was removed on day 11, and the patient was allowed oral feeding on day 12 when the TPN was terminated. A follow-up abdominal CT scan was performed on day 16 (Figure 3), which showed an almost complete resolution of the hematoma.

Figure 1. Abdominal X-ray showing a dilated stomach with air-fluid level. Scanty bowel gas was observed in the intestines. 
The patient was discharged on day 17 after admission.

\section{Discussion}

Duodenal hematoma in childhood is an uncommon condition, accounting for one to three percent of abdominal trauma cases. ${ }^{1-3}$ It is seen often in children and young adults with a male predominance, ${ }^{4,5}$ and is most commonly (>70\%) caused by blunt abdominal trauma. ${ }^{1-5}$ Most patients with this condition develop nausea, vomiting, and vague abdominal pain. In addition, a small subgroup of patients may suffer from intestinal obstruction., ${ }^{2,4}$ Generally, these symptoms usually present within six days after the trauma (Table 1). Occasionally, as in our case, the symptoms and signs of intestinal obstruction caused by duodenal hematoma after blunt trauma only appear two weeks after the incident. As a result the diagnosis of duodenal hematoma may be delayed or missed. A normal finding in the initial few days after the trauma does not guarantee an absence of future hematoma development. Follow-up of these patients is of the utmost importance.

A physical examination commonly reveals a lethargic dehydrated child. ${ }^{4}$ The abdomen is distended usually with epigastric or right upper quadrant tenderness. ${ }^{1}$ Occasionally a tender stomach may be palpable, and the bowel sounds are sluggish usually. ${ }^{2}$ Laboratory inves-

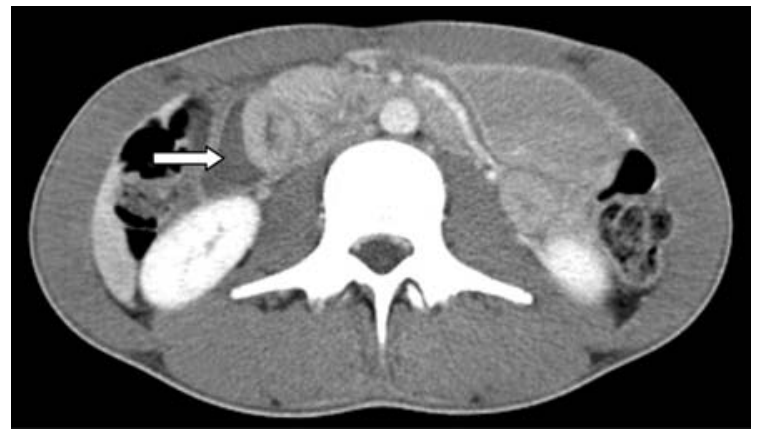

Figure 2. Computed tomography scan of the abdomen immediately after admission showing a hematoma lateral to the second part of the duodenum (arrow).

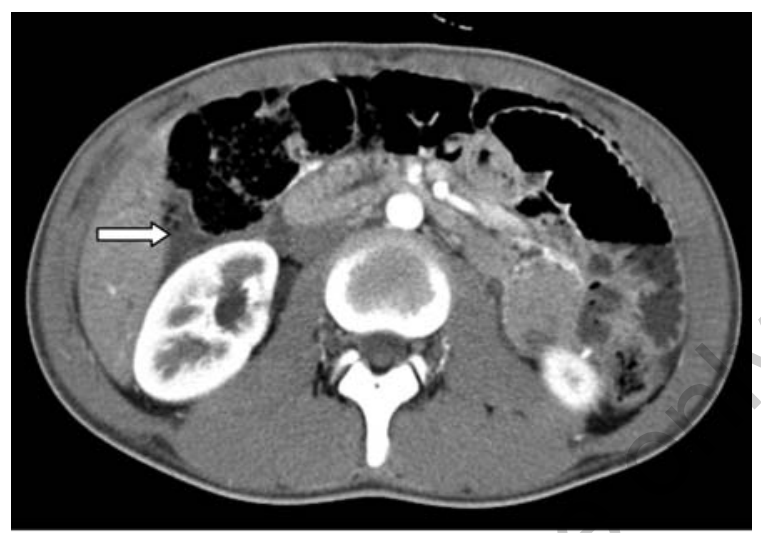

Figure 3. Follow-up computed tomography scan of the abdomen 16 days after admission showing the almost complete resolution of the hematoma (arrow).

tigations are of limited value, and may show a mild degree of anemia as well as leukocytosis. ${ }^{2}$ In cases of severe vomiting, examination of the serum electrolytes may reveal a hypochloremic, hypokalemic metabolic alkalosis. ${ }^{4}$ In some cases, elevated amylase and bilirubin levels can be detected. ${ }^{14}$

Currently, an abdominal CT scan with con- trast is the most widely accepted modality in diagnosing duodenal hematoma. ${ }^{6}$ Usually, a rim of fluid can be seen next to the duodenum, signifying hemorrhage. The extravasations of contrast or pneumoperitoneum would suggest duodenal perforation instead of a hematoma. ${ }^{6,7}$ An abdominal X-ray may show a distended stomach with an air-fluid level together with

Table 1. Clinical presentation and management of traumatic duodenal hematoma in published articles within the last ten years.

\begin{tabular}{|c|c|c|c|c|c|c|}
\hline Authors & $\begin{array}{l}\text { Sex } \\
\text { / Age (yr) }\end{array}$ & $\begin{array}{l}\text { Cause of duodenal } \\
\text { hematoma }\end{array}$ & Presentation & $\begin{array}{l}\text { Days of } \\
\text { onset* }\end{array}$ & $\begin{array}{l}\text { Diagnostic } \\
\text { method }\end{array}$ & Treatment \\
\hline Iuchtman et al. ${ }^{1}$ & $\begin{array}{l}\text { Both/ } \\
2-14\end{array}$ & $\begin{array}{l}\text { Handlebar injuries ( } 4 \text { cases) } \\
\text { Sports injuries ( } 2 \text { cases) } \\
\text { Traffic accidents ( } 2 \text { cases) } \\
\text { Child abuse ( } 1 \text { case) }\end{array}$ & $\begin{array}{l}\text { Abdominal pain } \\
\text { Bilious vomiting } \\
\text { Feeding difficulty }\end{array}$ & $2-6$ & $\begin{array}{l}\text { Abdominal CT } \\
\text { Upper GI contrast study } \\
\text { OGD (if needed) }\end{array}$ & $\begin{array}{l}\text { Conservative ( } 7 \text { cases) } \\
\text { Operative drainage of } \\
\text { hematoma ( } 2 \text { cases })\end{array}$ \\
\hline Lu et al. ${ }^{11}$ & $\mathrm{M} / 12$ & Traumatic intussusception & $\begin{array}{l}\text { Abdominal pain } \\
\text { Bilious vomiting }\end{array}$ & 4 & Abdominal CT & Conservative \\
\hline Chien et al..$^{12}$ & $\mathrm{M} / 6$ & Bicycle handlebar blunt injury & $\begin{array}{l}\text { Abdominal pain } \\
\text { Bilious vomiting }\end{array}$ & 6 & $\begin{array}{l}\text { Abdominal CT } \\
\text { Upper GI contrast study }\end{array}$ & $\begin{array}{l}\text { Laparoscopic drainage of } \\
\text { hematoma } \\
\text { (Failed conservative management) }\end{array}$ \\
\hline Banieghbal et al. ${ }^{13}$ & $\mathrm{M} / 11$ & Blunt trauma by heavy metal frame & $\begin{array}{l}\text { Abdominal pain } \\
\text { Vomiting }\end{array}$ & 3 & $\begin{array}{l}\text { Abdominal CT } \\
\text { Upper GI contrast study }\end{array}$ & $\begin{array}{l}\text { Laparoscopic drainage of } \\
\text { hematoma } \\
\text { (Failed conservative management) }\end{array}$ \\
\hline Ikeda et al..$^{14}$ & $\mathrm{~F} / 7$ & Fell down while holding an infant & $\begin{array}{l}\text { Abdominal pain } \\
\text { Vomiting }\end{array}$ & 1 & Abdominal CT & Conservative \\
\hline Lin et $a l^{15}$ & $\mathrm{~F} / 10$ & Blunt trauma by wooden bed & $\begin{array}{l}\text { Abdominal pain } \\
\text { Bilious vomiting }\end{array}$ & 2 & Abdominal CT & Conservative \\
\hline Takishima et al. ${ }^{16}$ & $\mathrm{M} / 6$ & Bicycle handlebar blunt injury & $\begin{array}{l}\text { Abdominal pain } \\
\text { Repeated vomiting }\end{array}$ & 1 & $\begin{array}{l}\text { Abdominal CT } \\
\text { Upper GI contrast study }\end{array}$ & $\begin{array}{l}\text { Operative drainage of hematoma } \\
\text { (Failed conservative management) }\end{array}$ \\
\hline $\begin{array}{l}\text { Yeung et al. } \\
\text { (current case) }\end{array}$ & $\mathrm{M} / 15$ & Physical assault & $\begin{array}{l}\text { Abdominal pain } \\
\text { Vomiting }\end{array}$ & 14 & Abdominal CT & Conservative \\
\hline
\end{tabular}

*Refer to the number of days for the onset of symptoms after the trauma. 
signs of scanty bowel gas. Abdominal ultrasound, upper gastrointestinal endoscopy, and a contrast study of the gastrointestinal tract may be useful at times, provided that the clinical condition is stable. ${ }^{1,24-10}$ The clotting profile should be checked as well to rule out any underlying coagulopathy. ${ }^{1,8}$

The management of traumatic non-perforated duodenal hematoma causing intestinal obstruction is conservative mainly (Table 1). Nil-by-mouth and nasogastric decompression together with providing total parenteral nutrition is sufficient usually in managing the condition. ${ }^{5}$ The decreasing trend of nasogastric tube aspirates signifies the improvement of the condition. However, surgical intervention may be needed if there is significant acute blood loss, a large hematoma causing a pressure effect, or if the hematoma fails to resolve spontaneously.,10 Laparoscopic evacuation of the duodenal hematoma has shown promising results in various published case reports. ${ }^{1,12,13,16}$ Most patients will recover within two weeks' time, and a follow-up CT scan of the abdomen will be useful for monitoring the resolution of the hematoma. ${ }^{8,10}$

In conclusion, a duodenal hematoma commonly presents after blunt abdominal trauma in children. It may present as intestinal obstruction as late as two weeks after the incident. A contrast CT scan of the abdomen is the best modality to delineate the severity of the duodenal hematoma, and is excellent in monitoring the progress of the hematoma resolution. Usually conservative management is sufficient to treat the condition, but it may take up to two weeks for the hematoma to resolve totally. Surgical management is reserved only for cases that fail conservative care, which can be supported by the CT findings as well as a high nasogastric tube output. Laparoscopic approach in the drainage of a duodenal hematoma yields excellent results and should be adopted in daily practice.

\section{References}

1. Iuchtman M, Steiner T, Faierman T, et al. Post-traumatic intramural duodenal hematoma in children. Isr Med Assoc J 2006;8:95-7.

2. de Bree E, Schoretsanitis G, Melissas J, et al. Intramural haematoma of the duodenum: a rare cause of duodenal obstruction. Acta Gastroenterol Belg 1998;61:485-7.

3. Ladd AP, West KW, Rouse TM, et al. Surgical management of duodenal injuries in children. Surgery 2002;132:748-52.

4. Jones WR, Hardin WJ, Davis JT, et al. Intramural hematoma of the duodenum: a review of the literature and case report. Ann Surg 1971;173:534-44.

5. Blocksom JM, Tyburski JG, Sohn RL, et al. Prognostic determinants in duodenal injuries. Am Surg 2004;70:248-55.

6. Kunin JR, Korobkin M, Ellis JH, et al. Duodenal injuries caused by blunt abdominal trauma: value of CT in differentiating perforation from hematoma. Am J Roentgenol 1993;160:1221-3.

7. Shilyansky J, Pearl RH, Kreller M, et al. Diagnosis and management of duodenal injuries in children. J Pediatr Surg 1997; 32:880-6.
8. Megremis S, Segkos N, Andrianaki A, et al. Sonographic diagnosis and monitoring of an obstructing duodenal hematoma after blunt trauma: correlation with computed tomographic and surgical findings. J Ultrasound Med 2004;23:1679-83.

9. Clendenon JN, Meyers RL, Nance ML, et al. Management of duodenal injuries in children. J Pediatr Surg 2004;39:964-8.

10. Touloukian RJ. Protocol for the nonoperative treatment of obstructing intramural duodenal hematoma during childhood. Am J Surg 1983;145:330-4.

11. Lu SJ, Goh PS. Traumatic intussusception with intramural haematoma. Pediatr Radiol 2009;39:403-5.

12. Chien JH, Ho TY, Shih-Peng L, et al. Acquired duodenal obstruction in children. Pediatr Neonatol 2008;49:193-6.

13. Banieghbal B, Vermaak C, Beale $P$. Laparoscopic drainage of a post-traumatic intramural duodenal hematoma in a child. J Laparoendosc Adv Surg Tech A 2008; 18:469-72.

14. Ikeda $\mathrm{T}$, Koshinaga $\mathrm{T}$, Inoue $\mathrm{M}$, et al. Traumatic intramural hematoma of duodenum with thrombasthenia in childhood. Pediatr Int 2007;49:668-71.

15. Lin YC, Chen Y, Yeh SJ. Traumatic intramural hematoma of the duodenum: report of one case. Acta Paediatr Taiwan 2004; 45:343-5.

16. Takishima T, Hirata M, Kataoka Y, et al. Delayed development of obstructive jaundice and pancreatitis resulting from traumatic intramural hematoma of the duodenum: report of a case requiring deferred laparotomy. J Trauma 2000;49:160-2. 